\title{
DESIGNING MODERN INFORMATICS EDUCATION FOR FUTURE MANAGERS AND ADVANCED USERS ACCORDING TO THEIR KNOWLEDGE BASE
}

\author{
Libuša Révészová
}

\section{Introduction}

Knowledge, the implementation of information and communication technologies (ICT) and innovations are considered to be the key factors of success that can ensure economic growth for individuals, companies even for whole countries. It is not different in the school environment. As well as in the economic sphere also in the school environment it is necessary to count with a minimal stability and certainty. The only thing that is certain in today's world is permanent change. For successful existence in this turbulent environment it is very important to learn how to cope with changes and the quickly transforming world.

The development of economy and a rise of living standards directly depend on knowledge of a generation and the proper usage of information which help with educating society, creating new scientific products and improving technologies. Dynamic changes in society and labor market require modern, flexible, innovative and creative possibilities of education. New skills for knowledge society are not only classical literacy (reading, writing, counting), but also digital literacy and good creative, logical and critical thinking.

It is necessary, especially for higher education institutions, to search for the new possibilities of improving the skills of future specialists and professionals, developing individual abilities and acquiring high level professional competences. The system of university education is one of the basic parts of education, culture, teaching, social welfare and economic development in every country. University education has been accepted as the foundation for public priority, economic prosperity and life quality. The institutions of university education are capable of training an educated, intelligent and knowledgeable society and raising national intellectual and creative potential (Lamanuskas, Augiene, \& Makarskaite-Petkeviciene, 2012).

\section{Theoretical Background and Current Issues}

\subsection{Informatics and ICT in Business Environment}

Changes of economic environment were commenced by scientific and technical progress of the first half of the 20th century. Construction and massive spread and extent of computer and its use as well as extensive conglomerate of technical means and technologies, often referred to as to information or informationcommunication technologies. Now Information society starts to transform into a different, more organized form, so called knowledge society (Kelemen et al., 2007; Soltes \& Gavurova, 2014). These changes cause significant social impacts. Institutions, organizations, enterprises focus more on getting employees who excel in their knowledge. It is also needed to be able to change knowledge into effective work. That is linked to a way of "system thinking" which makes us see things in relations. Education and learning become the key interest of people and organizations. Investment into immaterial capital is nowadays an important sum in most companies (Bureš, 2007).

The current business environment is characterized as highly turbulent, influenced by modern ICT, globalization, short innovation, production cycles and employee mobility. Progressive advanced companies show it is necessary to possess data, information, and knowledge and to value the experience of their 
employees. The need for new knowledge and skills requires that employees improve their competencies, skills and knowledge continually.

The economics literature emphasizes the importance of human capital, seen as the result of education and training (Lucas, 1998), and innovativeness, as reflected in R\&D efforts (Aghion \& Howitt, 1992) as determinants of growth at the economy-wide level. At the firm level, educated and trained employees and R\&D activities are seen as inputs to the production process which directly affects output (Barron \& Kreps, 1999).

Human resource systems can contribute to sustained competitive advantage through facilitating the development of competencies that are firm specific, produce complex social relationships, are embedded in a firm's history and culture, and generate tacit organizational knowledge (Lado \& Wilson, 1994). Moreover, competencies are fundamentally information based invisible assets that can be accumulated by careful planning and executed practice of organizational learning (Pucik, 1988).

Current business entities are forced to consistently improve their products and services. They have to utilize information systems, ICT and modern management methods. This is the only way they can succeed in such competitive environments. The information aspects of the management at all levels have a very important function in increasing competitiveness and management quality of all economic systems. Nowadays many managers in a higher position are expected to be information managers as well (Earl, 2000). They have to be involved in analysis, modeling and building of the effective IS of the companies and organizations.

\subsection{Informatics and ICT in Slovak Education System}

The success of Europe 2020 (European Commission, 2011) (the competitiveness and the innovation capability of European industry and social cohesion) depends on the strategic and effective use of ICT and the knowledge, skills, competences and inventiveness of the European workforce and citizens. The role of ICT on productivity and standards of living seems to be critical, because e-skills shortages, gaps and mismatches as well as a persistent digital divide will affect negatively productivity growth, competitiveness, innovation, employment and social cohesion in Europe, as we can read in (European Commission, 2007) - ICT, e-Skills for the 21st Century. With developing technology, it is necessary to widen e-skills by demand of creativity, innovation and higherlevel conceptual skills and competencies.

Our educational system should be able to react appropriately to the development and trends in the upcoming knowledge society. The most recent National reform programme in the Slovak Republic from 2014 (Národný program reforiem Slovenskej republiky, 2014), presents actions to fulfill targets contained in the strategy Europe 2020 (European Commission, 2011).

An Action plan (Akčný plán Národného programu reforiem Slovenskej republiky, 2014), following the National reform programme of $\mathrm{SR}$, defines tasks in particular fields. Activities of the Action plan demands from civil service employees, lawyers, medical workers, businessmen but even from ordinary citizens knowledge of IS, abilities to analyze processes as well as specify functionality requests on the IS being built and on IS management.

The first step towards informatization of schools in Slovakia was launching the project Infovek in 1999 (Sýkora, 2000). The document accepted by the Slovak government in 2008 Strategy of informatization of regional education (Stratégia informatizácie regionálneho školstva, 2008), defined a key government target - in four years to bring Slovak educational system closer to European schools preparing students for information society.

Another government document released in 2013 is Digipedia - a concept of informatization of the educational resort with an outlook till 2020. The concept presents digitization as one of the most effective tools for Slovak teachers and scientists how to achieve better results in education and research (MINEDU, 2013).

Determined targets and priorities should be imported into the basic curricular documents as well as into the Educational framework which adjusts lessons allocation so that the declared efforts could be transformed into educational process. However if we have a look at the for example Educational framework for secondary schools (MINEDU, 2011), the real situation does not testify to the proclaimed interests and efforts. The subject Informatics has the second lowest lessons allocation which is only 3 lessons in the 1 st up to the 4th (5th to 8 th) year in the higher secondary educational stage. Insufficient is the ICT integration into 
the tuition of other subjects, acute is also lack of competent qualified teachers in the field of informatics and ICT use.

While building a research tool we analyzed the basic curriculum document which is binding for the secondary stage of education in secondary schools State educational program for the subject Informatics ISCED 3A (National Institute for Education, 2012) especially targets, content and performance standard.

In recent years, several advanced countries have declared the intention to transform their ICT school subject into a new Computer Science, Informatics, or Computing education, with the emphasis on developing computational thinking, programming, designing computational systems and other basic concepts of Informatics. In Slovakia the theoretical conception of the school Informatics at the primary and secondary stages can be approximately characterized by the following principles:

- It is not the ICT in education, but Informatics. Both components are necessary in modern education: integration of ICT into learning processes, and also a separate subject focused on the concepts of Informatics or Computing.

- Informatics is a general (opposed to vocational) subject, for every student, without regard to his or her future professional profile and the degree of achieved education.

- Programming is considered an inseparable and core constituent of the school Informatics. There were controversial and not very successful attempts of the $80 \mathrm{~s}$ and the 90 s to implement the concept of 'programming for everybody' in every secondary school. Today we believe that educational programming can flourish only if we manage to adopt original ideas e.g. of Papert or Resnick about programming as a tool for thinking, exploring, and socializing, as an opportunity to create new playful learning contexts (Kalaš \& Gujberová, 2013).

In general, we can see development and output of our educational system in the field of Informatics and using ICT we can see in general at national level in e.g. (Velšic, 2013; Pudło \& Gavurova, 2012; 2013). We also can compare us with other countries via results of international surveys, for example OECD PIAAC Survey of Adult Skills - Problem solving in technology rich environments (OECD, 2013).
The Survey of Adult Skills defines Problem solving in technology-rich environments in (OECD, 2012) as using digital technology, communication tools and networks to acquire and evaluate information, communicate with others and perform practical tasks. It focuses on the abilities to solve problems for personal, work and civic purposes by setting up appropriate goals and plans, and accessing and making use of information through computers and computer networks.

\subsection{Current Trends in Business Informatics and Using ICT}

Informatics, ICT and computer networks penetrated into all aspects of activities where they enable us to work by brand new ways and create new values. Computer and the Internet have brought to companies unprecedented opportunities of mutual connection and partnerships building (Kelemen et al., 2007).

Much different prognosis deals with the trends of Informatics and ICT field, while the one which is most commonly used by ICT professionals is a prediction designed by Gartner Company called Hype cycle that tracks the different available technologies in their phase of growth, phase of decline of interest till their stabilization position. Gartner's 2015 Hype Cycle for Emerging Technologies (Gartner, 2015), identifies the computing innovations that companies and organizations should monitor. Now it mostly supports digital marketing, digital business and autonomous. In the field of the digital marketing enterprises focus on new and more sophisticated ways (e.g. via mobile, social, cloud and information) to reach consumers, who are more willing to participate in marketing efforts to gain greater social connection, or product and service value. Digital business is on higher level and focuses on the convergence of people, business and things. The Internet of Things (IoT) and the concept of blurring the physical and virtual worlds are strong concepts. Physical assets become digitalized and become equal actors in the business value chain alongside already-digital entities, such as systems and apps. Autonomous is defined by an enterprise's ability to leverage technologies that provide humanlike or human-replacing capabilities. Using autonomous vehicles to move people or products and using cognitive systems to recommend a potential structure for an answer to an email, write texts or answer 
customer questions are all examples that mark the autonomous stage (Gartner, 2015).

As enterprises continue the journey to becoming digital businesses, identifying and employing the right technologies at the right time will be critical.

Other expected trends in the field of using ICT, which can be found e.g. in (Gartner, 2014a; 2014b; 2014c) are:

- any function on any device, anywhere and anytime; BYOD (Bring Your Own Device - bring your own equipment to working environment);

- smarter things - as mobile robots, the loT, the wireless device power, machine-tomachine communication services, mesh networks sensors, home health monitoring;

- Big data, global computing power at low prices - the world presented by almost endless analytical understanding, computational power and continuously and effectively improving cost of it, businesses can better understand their customers and effectively prevent fraud;

- human communication technologies technologies, which communicate with people and vice versa by much more human, more natural;

- future of payment - no cash, all transactions are electronic, which helps companies to trace and increase efficiency of payments, and customers increase comfort and safety;

- 3D printing; cloud computing, process modeling, analysis of social networks, etc.

\section{Research Problems Formulation}

The requirements of the all school levels graduates' informational competences as well as the requirements of their creativity, their ability to solve problems, which don't have algorithmic methods for solving, are increasing in the knowledge economy environment.

It is obvious that support and development of information competences, skills and computer literacy of all users should be the main interest. It is obvious as well, that the system of education has to be customized according to these social requirements. The required state and the reality do not have to meet though. However despite growing interest and investment in the area of ICT, important gaps remain in the current knowledge base and abilities of all type ICT users (see e.g. OECD (2012), OECD (2013), Velšic (2013)).
That is why we focused on real ICT skills and knowledge of our students - future advanced users and managers in our research. The important queries of our questionnaire survey are:

- What is the students' knowledge base gained during their past education in the field of computer science/informatics?

- What are their ICT competences?

- How can they use their knowledge, skills and competences?

These are the questions we have been dealing with since academic year 2003/2004. Using a questionnaire administrated on first seminars of Informatics I Course we search for extent and content of compulsory education in the field of informatics/computer science and ICT at secondary schools. In close connection with result of questionnaire evaluation we investigate what are currently the competence requirements concerning the informatics and using ICT of non-professional in computer science?

Our effort is focused on designing a modern education system for future advanced users/ managers at an area of "understanding and using business informatics and ICT". This means to provide education in accordance with practice demands, on current knowledge basis of our students - graduates of secondary schools.

\section{Data Collection, Methods, and Results of Questionnaire Survey}

We created the questionnaire entries based on current legislation, pedagogical documentation and standards, currently they are e.g. (ECDL Foundation, 2013), (National Institute for Education, 2012), (MINEDU, 2011). The aim was to compare results, developments and improvements in a longer time period. For this reason we did not modify the questionnaire entries during the research and we provided some formal modifications in a minimal possible way. Annually we have been monitoring the extent and the content of the education in the field of Informatics. On the first seminar of Informatics I Course in 90 minutes students answer questions focused on number of obligatory lessons and the content these lessons comprised. The questionnaire contains apart from the closed items also open items concerning information systems, type of IS, life cycle of IS, modeling and the work with them. 


\section{Informační management}

We also assess the students' abilities to use their knowledge and skills to specify users' requirements using analysis and evaluation of developed tasks at the end of the questionnaire. The students are asked to specify a requirement on simple IS (by text and graphically). The task is to build an IS in small rental (e.g. DVD), where we want to install new electronic IS based on modern ICT instead of "old-styled paper" one. Their formulation of user requirements should be understood by professional systems analysts and software engineers, who farther analyze these requirements and consequently design IS according to these requirements. In this task students have to demonstrate their ability to use informatics knowledge, ICT competences, communication tools and networks to acquire and evaluate information, communicate with others and perform practical tasks.

We use methods of quantitative and qualitative analysis to assess these students' projects. To compare the level of ICT skills and information competences of secondary school graduates and development in the education system we present and compare evaluation of student responses from the year 2003 to 2014 .

\subsection{Characteristics of the Respondents}

The sample of our research consists of all secondary school graduates, who entered first year at Faculty of Economics Technical University of Košice in years 2003-2014. We only have the possibility to influence and adjust parameters of informatics education for these students; we did not extent our research to the other faculties. Students in the studied sample are secondary school graduates from Eastern Slovakian Region in more than $95 \%$ of cases.

Basic information about the sample of respondents are as follows:

- total number of respondents over the presented period: 1,921 graduates of secondary schools, mainly from the region of Eastern Slovakia and Košice;

- Grammar school (GS) graduates: 1,669 students (87\%);

- Business school (BS) graduates: 234 students (12\%);

- Other school (OS) graduates: 18 students $(1 \%)$.

Numbers of respondents in searched period and type of graduates' secondary school presents Tab. 1 in details.

\section{Tab. 1: Number of respondents and types of secondary schools}

\begin{tabular}{|c|c|c|c|c|c|c|c|c|c|c|c|c|}
\hline Year & 2003 & 2004 & 2005 & 2006 & 2007 & 2008 & 2009 & 2010 & 2011 & 2012 & 2013 & 2014 \\
\hline GS & 113 & 144 & 140 & 136 & 141 & 149 & 166 & 140 & 149 & 125 & 129 & 137 \\
\hline BS & 32 & 25 & 17 & 18 & 20 & 16 & 11 & 22 & 9 & 17 & 22 & 25 \\
\hline OS & 2 & 2 & 1 & 0 & 2 & 1 & 0 & 3 & 0 & 2 & 1 & 4 \\
\hline Total & 147 & 171 & 158 & 154 & 163 & 166 & 177 & 165 & 158 & 144 & 152 & 166 \\
\hline
\end{tabular}

Source: own

Within the first part of questionnaire we asked our students the question: How many obligatory informatics lessons did you get over at secondary school in particular school years? As we can see in the Fig. 1, despite the increasing importance of Informatics and ICT competences the number of lessons devoted to this subject in secondary schools is very low.

\subsection{Results of Questionnaires Evaluation}

Current standard of European Computer Driving Licence version 5.0 (ECDL, 2013) and basic pedagogical documents were the base for designing the part of the questionnaire concerned on finding out the level of students' informatics knowledge and competences. We focused on:

1. Basics of Informatics and ICT;

2. Working with computer and administration of files;

3. Text processing;

4. Spread sheet programs;

5. Usage of databases;

6. Presentation;

7. Web browsing and network communication.

Questions in this part of the questionnaire were formulated as following: Did you deal 


\section{Fig. 1: The average number of obligatory informatics lessons at secondary schools}

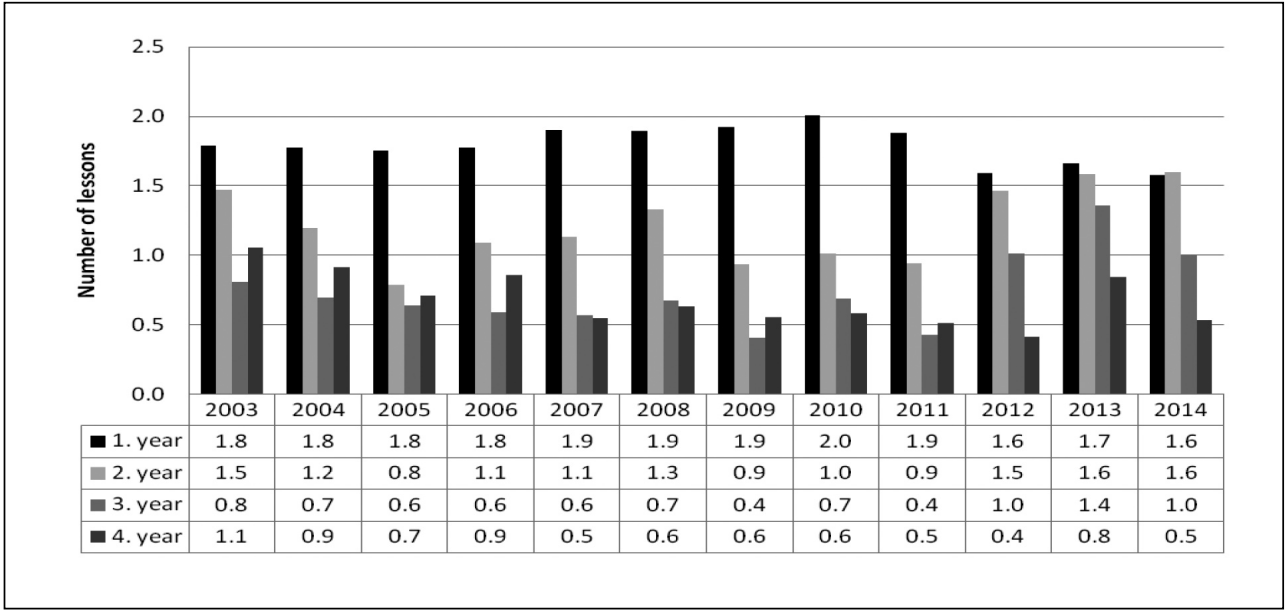

Source: own

or work with the next terms, programs and applications " * "? The sign * in the question means following terms/fields: informatics elementary concepts (data, information, history, etc.), hardware (computer and its components, von Neumann architecture, etc.), operation system. The respondents had an option to choose only from answers "yes" or "no". In the Fig. 2, 3 and 4 with tables we present results of this part of the questionnaire, shifts and advancement in students' knowledge basis in monitored fields. We show an evaluation of the students' answers expressed as a percentage number of response, "yes".

\section{Fig. 2: \\ Comparison of achieved percentage of students who previously deal/worked with basic concepts, hardware and operation systems}

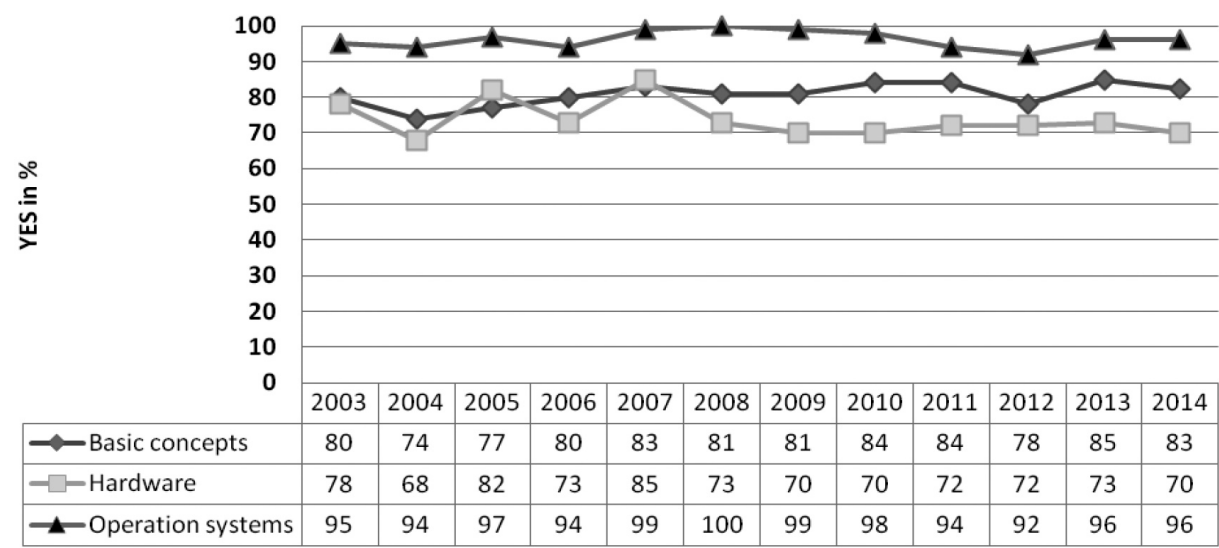


The situation in the field of basic concepts is changing only slightly, in spite of the fact that this field is a part of compulsory informatics curriculum. The surprising fact is that gradually fewer students are familiar with basic knowledge of computer hardware basics. As we expected the results in the field of understanding and working with operation systems have growing tendency.

Other areas of information competences we examined using similar tasks: "Did you deal with or work with next types of applications?" Students could answer following: text editor (MS Word, TEX, etc.), spread sheet program (MS Excel, Calc, etc.), software for presentation, graphic software and database system. Within the Fig. 3 with the table we present achieved percentage of students who had some experience with the mentioned applications.

Graph in the Fig. 3 illustrates high ratio of students who worked with text editor at their secondary school. It also shows an increase in working with spread sheet programs. As we can see the ratio of students who worked with software designed to make presentation has grown significantly. On the other hand, the number of students who had the opportunity to meet with database systems is slightly decreasing. In all the mentioned fields according to our survey applications of The Microsoft dominate in education.

\section{Comparison of achieved percentage of students who worked with the text
Fig. 3:
editor, spread sheet program, presentation and graphic software and database systems}

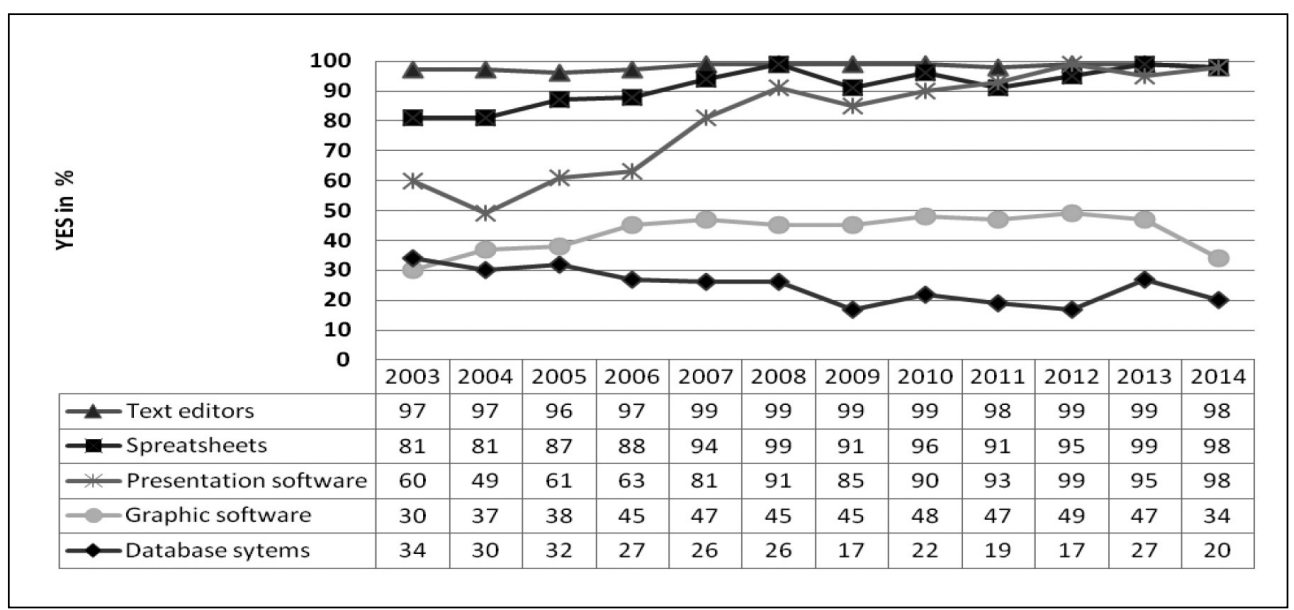

The ability to communicate via computer network also belongs to basic computer competences. In detail it means using internet services and understanding the basic rules of network communication, security issues. These are needed for solving the next problems and tasks in the questionnaire. As we can see in the Fig. 4 , in the last years almost all secondary school students worked with and used internet services (email, www, ICQ, Skype, etc.), especially the application for web browsing. Despite that fact, it is surprising that the number of students who are familiar with basic rules of computer networking e.g. basic of topology, how the Internet works, internet protocols, is stagnating. We expected that the low number of students familiar with basic knowledge of computer networks and Internet would start to increase, because of significant expansion of the Internet. As we can see the results prove different.

The surprising facts are presented in the Fig. 5. In the last three years gradually fewer students are familiar with programming, algorithms, web page creation and coding.

In the next part of the questionnaire there was the question: "Have you met the following terms: information system, types of information 

terms in the field of computer networks, the Internet, internet services and browser/search machine

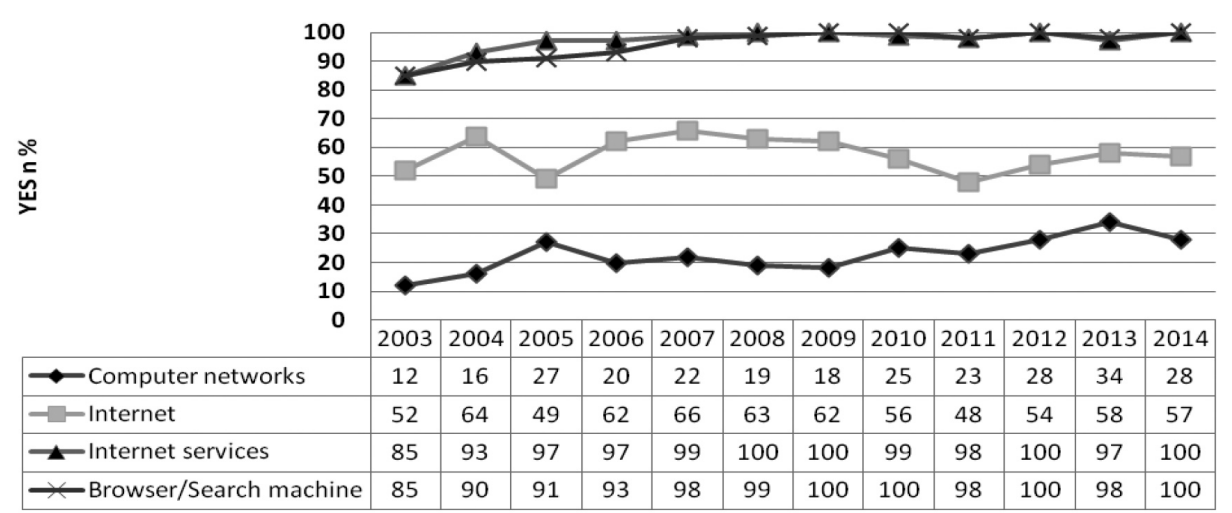
terms in the field of programming, algorithms, web page creation and coding

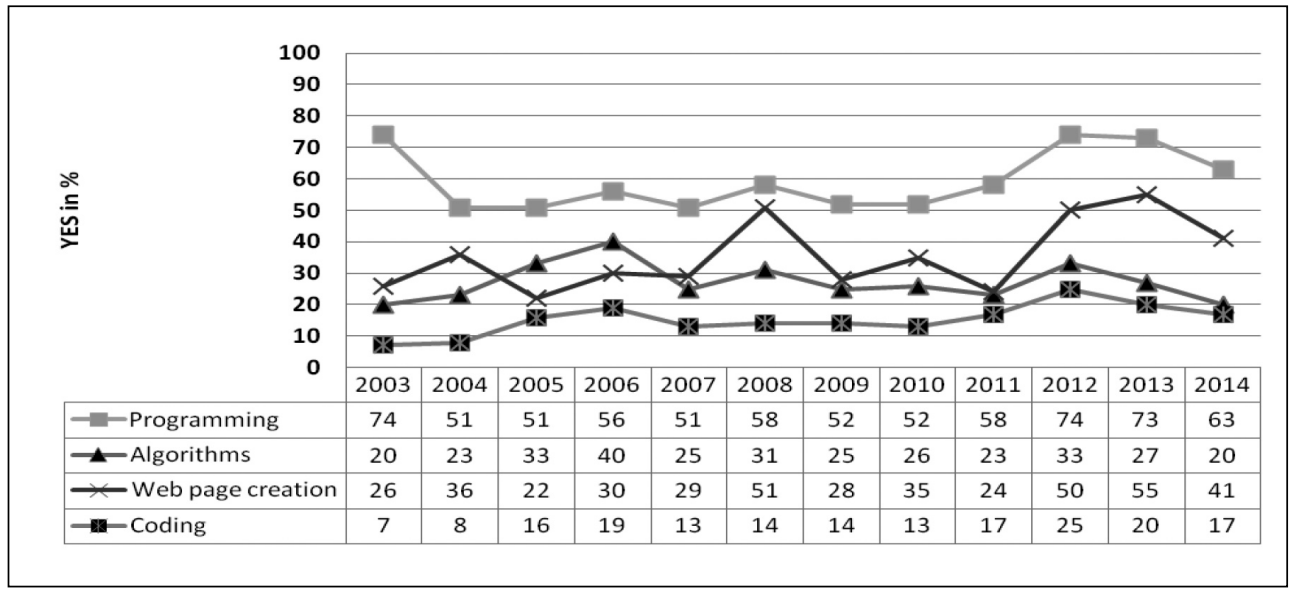

Source: own

systems, life cycle of information system and modeling of information system on the informatics/computer science lessons? Fig. 6 with the table presents obtained results.

In the average less than $20 \%$ of the students have had experience with IS and recognize the types of IS. Less than $1 \%$ specified dealing/working with modeling as a method of simplifying and recognition of real objects.

We also asked students to submit examples of information system from practical life with which they had met/worked so far. For the 


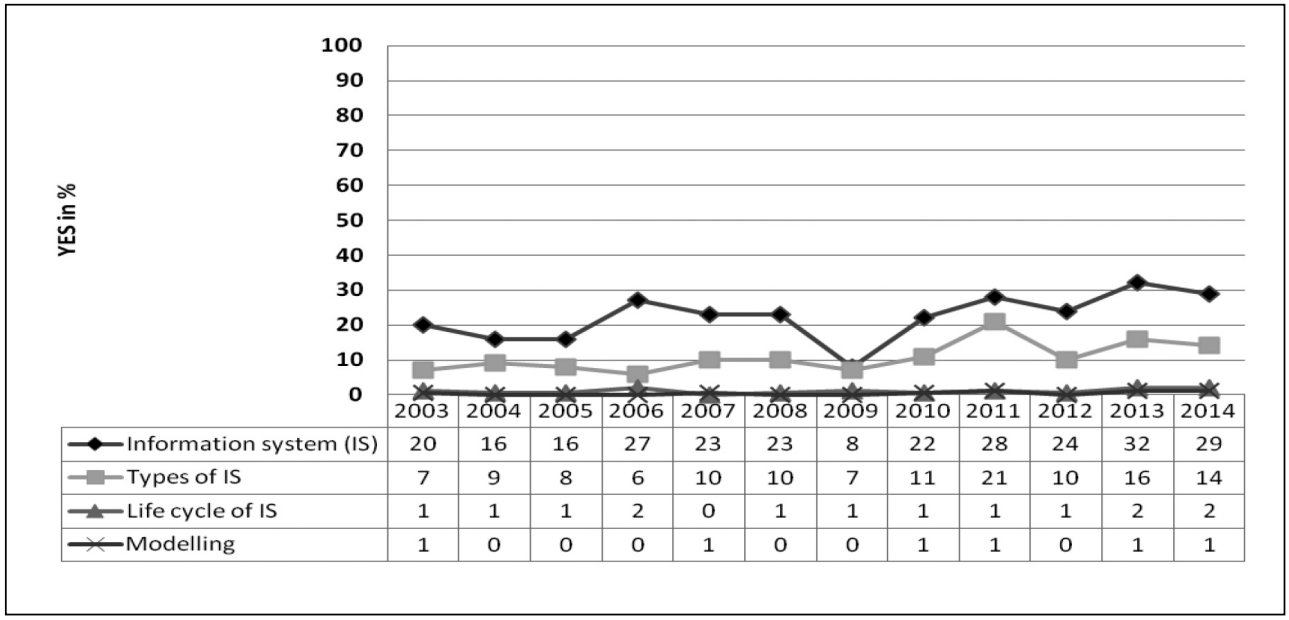

Source: own

watched time period in average $70 \%$ of students were not able to provide any example of used information system.

\subsection{The Real State of Higher Level Students' Information Competences}

In the last part of the questionnaire we asked students to describe a simple example of using IS in practical life and to write user requirements. The task was: Define/describe user requirements for a simple information system in a DVD rental where we want to install new and effective electronic IS based on modern ICT instead of "old-styled paper" IS.

Solving this task as well as Problem solving in technology-rich environments OECD PIAAC (OECD, 2012) represents the intersection of what are sometimes described as "computer literacy" skills (i.e. the capacity to use ICT tools and applications) and the cognitive skills required to solve problems. The objective is not to test proficiency in the use of ICT tools and applications in isolation, but rather to assess the capacity of students to use these tools, their knowledge and information competences to access, process, evaluate and analyze information effectively in a goal-oriented way.

We divided the students' user requirement formulations - projects according to the quality into following five levels:
- A - acceptable, it was possible to recognize functions and requirements of IS, there were structure and hierarchy between requirements, there were some graphical expressions.

- B - mostly continuous text with effort to design database tables, content and scope was partly incomplete.

- C - extensive continuous text with typical lack of exactness, structure, relationships, extent from $1 / 2$ sheets to 2 sheets.

- D - text in extent from few lines to $1 / 2$ of sheet, totally unsatisfactory.

- $\mathbf{E}$ - no elaboration, most of these students said: "I don't know what to write."

The results of the evaluation of "user requirements" formulation projects are shown in the Fig. 7.

The provided graphs present shifts which occurred or did not occur during estimated time periods in particular fields - extent of informatics teaching at secondary schools, and content of secondary school informatics. As we can see nearly $100 \%$ respondents are familiar with working with text editor, operating systems, using internet services and search machines, spreadsheet program and software for presentation. Relatively high percentage of students was familiar with informatics elementary terms, basics of hardware and 


\section{Fig. 7: Percentage evaluation of the user requirements formulation}

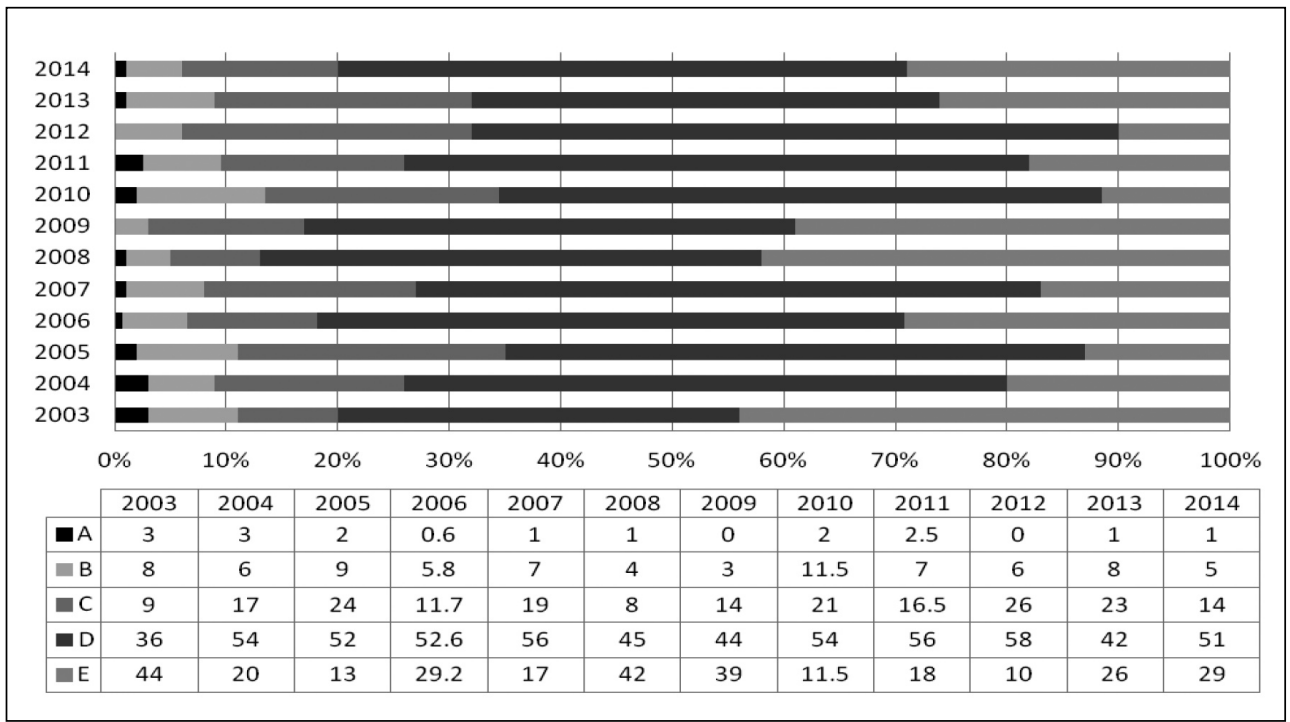

Source: own

architecture of computer, internet protocols programming languages. Also more than $20 \%$ of the students had already encountered with the term IS and more than $10 \%$ with IS typology. However when we look at the evaluation of user requirements at Fig. 7 only a small ratio of students was able to formulate in an acceptable way a simple IS assignment. Even level B showed inadequacies at solving these types of tasks. The other levels C, D and E cannot be considered acceptable.

We derived from the questionnaire evaluation that the education of Informatics at secondary schools is focused on handling with different packages of applications' programs. There is a lack of understanding of basic terms of modeling and IS, regardless of the fact, that students work with IS and modeling in some form "every day" in school and in the common life. Algorithmic approach, the using of knowledge for creating "something new" and interdisciplinary relations are often missing.

\section{Essential Characteristics of Informatics Course New Design}

In this section we will at first describe the reasons why we consider it important to educate users and non-professionals in business informatics, especially in the field of information systems. Afterwards we will describe teaching methods created on the basis of assessment of the current knowledge state on secondary school students and modern trends.

\subsection{Importance of Education in the Field of Business Informatics and IS}

Why it is necessary to provide all students - future managers and advanced users with proper education in the field of business informatics, IS and ICT competences? The answer can be found in the following sources.

Information systems are a scientific discipline with a global reach that investigates a development, use, and impact of ICT (Basl et al., 2011; Vymětal, 2009). Business Informatics as such constitutes a major scientific community within the IS discipline according to (Gála, Pour, \& Šedivá, 2009; Heinrich \& Riedl, 2013). In the articles of Voříšek, Pour and Buchalcevová (2015) and Soltes and Gavurova (2014) we can furthermore read that the required qualification of users and IT practitioners should be developed systematically. Management of 
business informatics has been in the spotlight of researchers and IT practitioners from all over the world for a number of decades. However, a rising complexity and heterogeneity of technological infrastructure and enterprise applications together with the growing possibilities of information service provision have contributed to a demanding management of business informatics. In particular, diverse options of IT service provision, i.e. apart from standard outsourcing of selected applications and services also various cloud computing models such as Software as a Service (SaaS), Platform as a Service (PaaS) and Infrastructure as a Service (laaS), significantly increase the number of stakeholders and business relationships a company may have. Nowadays, company management expects an improved effectiveness and reduced costs associated with IT services provision forcing IT executives to seek better methods for business informatics management (Voříšek, Pour, \& Buchalcevová, 2015).

According to the findings in (Werber, Rajkovič, Urh, \& Žnidaršič, 2015) in order to take full advantage of the existing technology current owners and managers of small and micro-enterprises are aware that they should increase the level of their computer skills and knowledge, stay informed about new trends, developments in the ICT and acquire technical and managerial competences needed to effectively manage the IS. Training in using of PC based end-user tools, and their use for data analyses may also help owners, managers and employees to gain self-confidence in using ICT, and better exploit the available technology.

As we can read in (Gála, Pour, \& Šedivá, 2009), a current trend in business informatics is to strengthen the use of strategic applications i.e., enterprise applications that have a potential to deliver a competitive advantage. Such strategic applications include Business Intelligence, Competitive Intelligence, Customer Relationship Management, and various forms of electronic and mobile business applications.

\subsection{New Design of Informatics II Course}

Although computer science has been a regular subject in all levels of schools for a long time, there is still more and more discussion on how to teach computer science and what to teach: Should computer science education be oriented more towards its applications or more towards its fundamentals or more towards its social effects? How can we cope with the rapid developments of computer science and ICT with respect to curriculum development? (Schwill, 1998)

Many new different learning environments, tools, communities and pedagogies, supported by ICT, are currently available for every single learner instead of textbooks, blackboards and classical classroom teaching. For students it is more motivating, if they have to solve practical problems, a variety of used media can support students' learning and provide a deeper understanding of the content and concepts.

As university teachers, as researchers and as participants of project teams we have found out that the knowledge and abilities of everybody must possess in order to work effectively and succeed in knowledge economy and have been dramatically redefined. We consider changes in economic environment, development in computer science, development in the area of business informatics, enterprise modeling, using simulation, and extensive application of new knowledge in all areas of life. We decided to modernize and innovate the informatics education at our faculty based on the following:

- Analysis and assessment of the real state of students' knowledge and their abilities. We consider it a very important step in determining the content and methods of our effective teaching.

- Studying programs and curricula of advanced foreign universities in the field of Informatics, business informatics and ICT integration.

- Collection/gathering of educational requirements from the practice, labor market, employers, development and using ICT and changes in the economic environment.

Based on studying the accessible sources of literature e.g. (Basl et al., 2011), (Bureš, 2007), (Dale, 1969), (Drucker, 2001), (Eckstein, Manns, \& Voelter, 2001), (Hubweiser, Broy, \& Brauer, 1997), (Schwill, 1998), (Strawman, 2004), (Vořišek, Pour, \& Buchalcevová, 2015) the latest knowledge and trends in the field of ICT mentioned above, implementation and integration of IS, published experience of experts from the area of development, contents of foreign universities curriculums, contents for educating experts in the field of "business informatics" and software engineering, our 
own knowledge and skills we have decided for a concept of education in two parallel lines. The new structure of the Informatics II Course, used and adjusted during last ten years presents Tab. 2 .

Firstly, considering big differences in ICT knowledge and skills of secondary school graduates oblige us to keep the classic procedure in teaching the Informatics subjects. In structure very similar to ECDL standard students can learn basic terms, how to work in text editor environment, spread sheets, presentation software, database systems, and various web-services, which we consider vital for further correct understanding of possible work in business informatics.

The second, parallel line, where the business informatics and management of IS are the key themes, seems to be in the relation with modeling of the business processes. As a dominant method in this area we use problemoriented project teaching, while we are using the functionality of LMS Moodle environment.

\section{Tab. 2: New structure of the Informatics II Course}

Informatics II Course - second term - 13 weeks

\begin{tabular}{|c|c|c|c|c|c|}
\hline \multicolumn{6}{|c|}{ First line - classical way of teaching - lectures and exercises } \\
\hline \multicolumn{2}{|c|}{ MS Excel } & \multicolumn{2}{|c|}{ MS Access } & \multicolumn{2}{|c|}{ Test } \\
\hline \multicolumn{6}{|c|}{$\begin{array}{l}\text { Second parallel line - teaching/learning with application new attitude } \\
\text { The main aim is - Development of Project - User Requirements of Information System }\end{array}$} \\
\hline $\begin{array}{l}\text { Face to face } \\
\text { teaching, } \\
3 \text { lectures }\end{array}$ & $\begin{array}{c}\text { Project } \\
\text { proposal } \\
\text { via Moodle }\end{array}$ & $\begin{array}{l}\text { Project first } \\
\quad \text { draft } \\
\text { via Moodle }\end{array}$ & $\begin{array}{l}\text { e-learning, } \\
\text { learning-by doing, } \\
\text { providing feedback } \\
\text { via Moodle }\end{array}$ & $\begin{array}{l}\text { Project final } \\
\text { version via } \\
\text { Moodle }\end{array}$ & $\begin{array}{l}\text { Evaluation } \\
\text { Face to face } \\
\text { at the exam }\end{array}$ \\
\hline
\end{tabular}

Source: own

All our students find themselves at a position of a manager of a virtual company - in the role of IT executive such as Chief Information Officer (CIO) in ensuring continuous development and innovation of both IT applications and IT infrastructure. At project of specifying users' requirements they have to think about how to differ from the others, what kind of innovations they should bring into the model of the main process of a chosen company. They have to have by the method of learning-by-doing get knowledge of IS and its management.

The recommended structure of the user requirements project consists of four parts. In the first one, a student specifies the core business process by text and a graphic model. On this basis they create requirements on the IS in the second part of the task. They describe the functionality of the project in the third part using UML - use case diagram and the basis for the data model is a proposal of classes and their attributes using UML class diagram. The last part is a proposal of tables of relation database in MS Access environment.

In our course preparation we came out from well known facts that are concisely described by Fig. 8 - Dale's Cone of Experience (Dale, 1969). It is a model that incorporates several theories related to instructional design and learning processes and it is also a tool to help teachers and instructors make decisions about resources and activities.

Teachers/instructors should design instructional activities that build upon more reallife experiences. The most effective methods at the bottom, involves direct, purposeful learning experiences, such as hands-on or field experience. Today, this "learning by doing" has become known as "experiential learning" or "action learning".

The difficultly of the implemented problemoriented project education is related to both (as we can read e.g. in (OECD, 2012)) the cognitive demands and complexity of the tasks, and the range and nature of the tools and applications that the student is required to use to arrive at a solution. This difficult problem solving tasks tended to involve transferring information from one application to another, and then transforming that information in addition to requiring the student to follow a relatively complex sequence of actions. Students have to demonstrate 


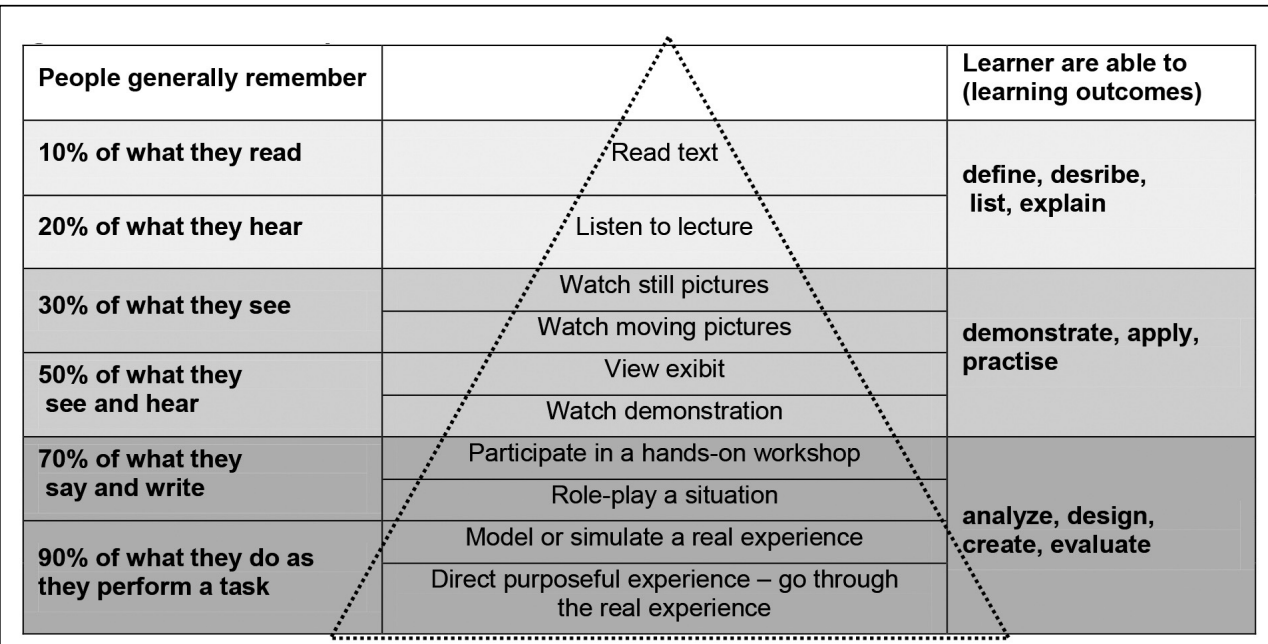

Source: Dale (1969)

sufficient familiarity with computers to use them to perform information-processing tasks and their ICT competences/skills in solving the problems commonly encountered in their roles as workers, citizens and consumers.

\section{Conclusions}

In the paper we presented new design of Informatics II Course based on evaluation of current students' knowledge base and level of their ICT competences. Those were evaluated based on annually realized questionnaire. Conclusions formulated in the previous sections are directly relevant for teaching realized on the Faculty of Economics, Technical University Kosice. In the process of questionnaire creation we drew from generally valid documents for secondary schools in Slovakia. In the sample of respondents there were mostly graduates from Eastern Slovakia Region therefore this allows us to assume that knowledge base and ICT competences on the other faculties especially in our region with non informatics focus would copy the described trends.

In order to prepare future managers with taking into account labor market requirements, students must be challenged with innovative tasks that focus on understanding and not only on memorization.
Benefits of better ICT skilled user and employee for all company and organizations can be observed in the following areas:

- Higher productivity and performance of the company/organization.

- Possibility of implementation new organizational forms, e.g. development of business nets, participation in supply chains.

- Increased added value of the product or services.

- Entry to new markets. Utilization of new business channels.

- New products or services, changing business processes.

- Responding to new business activities of competitors.

We developed an environment in which students solved a sequence of small assignments leading to one target task, which is similar to a programming (Schwill, 1998). Our experience shows that after taking the whole gradation of the assignments we had designed, students achieved better results when solving the target task. In spite of that, we believe that our approach gradually contributes to the development of systematic approach, logical and critical thinking and creativity. 


\section{References}

Aghion, P. E., \& Howitt, P. (1992). A model of growth through creative destruction. Econometrica, 60(2), 323-352. doi:10.2307/2951599.

Akčný plán Národného programu reforiem Slovenskej republiky. (2014). Retrieved November 5, 2015, from http://ec.europa. eu/europe2020/pdf/csr2014/annexnrp2014_ slovakia_sk.pdf.

Barron, J. N., \& Kreps, D. M. (1999). Strategic Human Resources: Frameworks for General Managers. New York: John Wiley and Sons.

Basl, J. et al. (2011). Inovace podnikových informačných systémů - Podpora konkurenceschopnosti podniků. Príbram: Professional Publishing.

Bureš, V. (2007). Znalostní management a proces jeho zavádění. Praha: Grada Publishing.

Dale, E. (1969). Audio-Visual Methods in Teaching (3rd ed.). New York: Holt, Rinehart \& Winston.

Drucker, P. F. (2001). To nejdůležitější z Druckera $v$ jednom svazku. Praha: Management Press.

Earl, M. (2000). Are ClOs Obsolete? Harvard Business Review, 78(2), 60.

ECDL Foundation. (2013). ECDL. Retrieved October 9, 2015, from www.ecdl.org.

Eckstein, J., Manns, M. L., \& Voelter, M. (2001). Pedagogical Patterns: Capturing Best Practices in Teaching Object Technology. Retrieved October 9, 2015, from http:// www.jeckstein.de/pdfs/softwarefocus.pdf. doi:10.1002/swf.19.

European Commission. (2011). Europe 2020' strategy - Council conclusions on the role of education and training in the implementation of the 'Europe 2020' strategy. Retrieved October 9, 2015, from http://eur-lex.europa.eu/ LexUriServ/LexUriServ.do?uri=OJ:C:2011: 070:0001:0003:EN:PDF.

European Commission. (2007). Information and communication technologies, e-Skills for the 21st Century. Retrieved October 9, 2015, from http://eur-lex.europa.eu/legal-content/SK/TXT/ PDF/?uri=CELEX:52007DC0496\&from=EN.

Gála, L., Pour, J., \& Šedivá, Z. (2009). Podniková informatika. Praha: Grada Publishing.

Gartner. (2014a). Fifteen Skills Critical to Success with Business Process Management.
Retrieved October 15, 2015, from http://www. gartner.com/newsroom/id/2674619.

Gartner. (2014b). Four Key Attributes of Customer Engagement. Retrieved October 9, 2015, from http://www.gartner.com/newsroom/ id/2689817.

Gartner. (2014c). Gartner Identifies the Top 10 Strategic Technology Trends for Smart Government. Retrieved October 15, 2015, from http://www.gartner.com/newsroom/id/2707617.

Gartner. (2015). Hype Cycle for Emerging Technologies. Retrieved October 9, 2015, from http://www.gartner.com/newsroom/id/3114217.

Heinrich, L. J., \& Riedl, R. (2013). Understanding the dominance and advocacy of the design oriented research approach in the business informatics community: a history-based examination. Journal of Information Technology, 28(1), 34-49. doi:10.1057/jit.2013.1.

Hubweiser, P., Broy, M., \& Brauer, W. A. (1997). New Approach in Teaching Information Technologies: Shifting Emphasis from Technology to Information. In Proceedings of the IFIP TC3 WG3.1/3.5 joint working conference on Information technology: supporting change through teacher education (pp. 115-121). London: Chapman \& Hall. doi:10.1007/978-0-387-35081-3_14.

Kalaš, I., \& Gujberová, M. (2013). Designing productive gradations of tasks in primary programming education. doi:10.1145/2532748.2532750.

Kelemen, J. et al. (2007). Pozvanie do znalostnej spoločnosti. Bratislava: lura Edition.

Lado, A. A., \& Wilson, M. C. (1994). Human resource systems and sustained competitive advantage: a competency-based perspective. Academic Management Review, 19(4), 699727. doi:10.5465/AMR.1994.9412190216.

Lamanuskas, V., Augiene, D., \& Makarskaite-Petkeviciene, R. (2012). Problems of University Education in Lithuania: Student Point of View. International Education Studies, 5(4), 196-211. doi:10.5539/ies.v5n4p196.

Lucas, R. E. (1998). On the mechanics of economic development. In D. Jacobs, E. Kalai, \& M. Kamien (Eds.), Frontiers of Research in Economic Theory (pp. 61-71). Econometric Society Monographs. doi:10.1017/ CCOL0521632226.

Ministerstvo školstva, vedy, výskumu a športu SR. MINEDU. (2011). Rámcový 
učebný plán pre gymnáziá so štvorročným a osemročným štúdiom s vyučovacím jazykom slovenským, 2011-7915/18752:1922. Retrieved October 9, 2015, from http://www.statpedu.sk/files/documents/svp/ gymnazia/rup3_sjog.pdf.

Ministerstvo školstva, vedy, výskumu a športu SR. MINEDU. (2013). Digipedia Koncepcia informatizácie rezortu školstva $s$ výhl'adom do roku 2020. Retrieved October 9, 2015, from https://www.iedu.sk/digipedia/ Documents/4796.pdf.

Národný program reforiem Slovenskej republiky. (2014). Retrieved October 9, 2015, from http://ec.europa.eu/europe2020/pdf/ csr2014/nrp2014 slovakia sk.pdf.

National Institute for Education. (2012). Štátny vzdelávací program pre gymnázia ISCED-3a. Retrieved October 9, 2015, from http://www.statpedu.sk/files/documents/svp/ gymnazia/vzdelavacie_oblasti/informatika_ isced3a.pdf.

OECD. (2012). Literacy, Numeracy and Problem Solving in Technology-Rich Environments: Framework for the OECD Survey of Adult Skills. Paris: OECD Publishing. doi:10.1787/9789264128859-en.

OECD. (2013). Skills Outlook 2013: First Results from the Survey of Adult Skills. Paris: OECD Publishing. doi:10.1787/9789264204256-en.

Pucik, V. (1988). Strategic alliances, organizational learning and competitive advantage: the HRM Agenda. Human Resource Management, 27(1), 77-93. doi:10.1002/ hrm.3930270105.

Pudło, P., \& Gavurová, B. (2012). Experimental learning in higher education, using simulation games as learning tool. In SGEM 2012: 12th International Multidisciplinary Scientific GeoConference: conference proceedings : Volume 3 : 17-23 June, 2012, Albena, Bulgaria (pp. 1093-1100). Sofia: STEF92 Technology. doi:10.5593/sgem2012/ s23.v3009.

Pudło, P., \& Gavurová, B. (2013). Experimental teaching methods in higher education - practical application. In SGEM 2013: 13th International Multidisciplinary Scientific Geoconference : Ecology, Economics, Education and Legislation : vol. 2: 16-22 June, 2013, Albena, Bulgaria (pp. 423-428). Sofia: STEF92 Technology. doi:10.5593/sgem2013/ be5.v2/s22.010.
Schwill, A. (1998). Computer Science Education Based on Fundamental Ideas. Retrieved October 9, 2015, from http://ddi.unimuenster.de/didaktik/Forschung/lsrael97.pdf.

Soltes, V., \& Gavurova, B. (2014). Innovation policy as the main accelerator of increasing the competitiveness of small and medium-sized enterprises in Slovakia. In Procedia Economics and Finance, Emerging Markets Queries in Finance and Business (pp. 1478-1485). Elsevier. doi:10.1016/S2212-5671(14)00614-5.

Stratégia informatizácie regionálneho školstva. (2008). Retrieved October 9, 2015, from http://www.minedu.sk/data/USERDATA/ ISKOL/ISDOC/20080220_strategia_ informatizacie RS.rtf.

Strawman, J. (2004). Computing curricula 2004 overview report including a guide to undergraduate degree programmes in computing. Strawman Draft, ACM/AIS/ IEEE. Retrieved October 9, 2015, from http://www.acm.org/education/curricula.html.

Sýkora, P. (2000). Filozofia projektu Infovek. Retrieved October 9, 2015, from http:// www.infovek.sk/archivwebu/konferencia/2000/ prispevky/filozofia.html.

Velšic, M. (2013). Digitálna gramotnost' na Slovensku 2013. Bratislava: Inštitút pre verejné otázky.

Voříšek, J., Pour, J., \& Buchalcevová, A. (2015). Management of business informatics model - principles and practices. E\&M Ekonomie a Management, 18(3), 160-173. doi:10.15240/tul/001/2015-3-014.

Vymětal, D. (2009). Informačni systémy $\checkmark$ podnicích, teorie a praxe projektování. Praha: Grada Publishing.

Werber, B., Rajkovič, U., Urh, M., \& Žnidaršič, A. (2015). Computer Literacy and Use of ICT as Key Factors of Micro-Enterprise Success. E\&M Ekonomie a Management, 18(2), 165-182. doi:10.15240/tul/001/2015-2-012.

RNDr. Libuša Révészová, Ph.D.

Technical University of Košice

Faculty of Economics

Department of Applied Mathematics and Business Informatics libusa.reveszova@tuke.sk 


\section{Abstract}

\section{DESIGNING MODERN INFORMATICS EDUCATION FOR FUTURE MANAGERS AND ADVANCED USERS ACCORDING TO THEIR KNOWLEDGE BASE}

\section{Libuša Révészová}

The main question we are dealing with is how to teach/educate the future managers - advanced users of business informatics, ICT and information systems. As a very important step in determining the content and method of teaching we consider an evaluation of the knowledge base of students who enter the first year at the Faculty of Economics Technical University of Košice. In the first seminar in subject called Informatics I students fill in questionnaires which are focused on their general knowledge of informatics/computer science and basic terms of IS. In the paper we present evaluation of our questionnaire survey in the period 2003-2014. Conclusions formulated in the paper are directly relevant for teaching realized on the Faculty of Economics, Technical University Kosice. In the process of questionnaire creation we drew from generally valid documents for secondary schools in Slovakia. In the sample of respondents there were mostly graduates from Eastern Slovakia Region therefore this allows us to assume that knowledge base and ICT competences on the other faculties especially in our region with non informatics focus would copy the described trends. We also present our innovative manner of informatics education based on modeling, simulation and on a well known opinion that "no kind of teaching can replace the personal experience". As a dominant form we use problem-oriented project teaching. Students find themselves in a position of a manager of a virtual company, at project of specifying users' requirements The paper deals with the experience in teaching, we present recommended structure of the user requirements project and we also discuss the body of knowledge and methods which have been implemented into the subject Informatics II. In the proposed innovative way of teaching we are trying to transform solving problem process into an active process of cognition.

Key Words: Education, informatics, ICT competences, student's evaluation, business informatics.

JEL Classification: A20, 121, 123, 034.

DOI: 10.15240/tul/001/2016-4-013 